\title{
FOOD SUPPLIES IN RE LATION TO HUMAN NEEDS PART 1. REQUIREMENTS FOR HEALTH
}

\author{
Chairman, Dr. A. Davidson
}

Dr. A. Davidson (Chief Medical Officer for Scotland): I consider it a privilege to be here today and an honour to be asked to take the chair at this, the first scientific meeting of the Scottish Group of The Nutrition Society. The happy inspiration of establishing a Scottish Group of the Society must have originated in the minds of knowledgeable people who appreciated what Scotland has already done to advance the science of nutrition and the valuable contribution this country can still make to further advances.

It is now more than 25 years ago since I had the good fortune to be associated as a student of advanced physiology and later as an assistant in Noel Paton's laboratory in Glasgow where, unknown to me at the time, the foundations of much of the present structure of nutrition were being laid. At that time the workers in the laboratory included, apart from Noel Paton himself, your Chairman, Sir John Orr, Professor E. P. Cathcart, Dame Louise Mcllroy, Leonard Findlay and others. You will readily appreciate from these names that there was a happy combination of scientists and clinicians who had in view not only the search for new knowledge of nutrition, but also what is of prime importance, the practical application of any advances in the subject. Since these days the science of nutrition has advanced considerably in many directions in Scotland itself and I feel sure that the formation of this Group is yet another phase in its development, which will continue the tradition set up by these Scottish pioneers.

The Society will have many interesting subjects to discuss and many difficult problems to unravel. Those of us concerned in the application of nutritional knowledge will watch the Society's deliberations with great interest and look to it for advice and guidance. I feel sure that under the chairmanship of Sir John Orr all available help will be forthcoming to those working in the wider field of preventive medicine.

Dr. Davidson went on to discuss the range of problems involved in the study of nutrition and the urgent need for a yard stick by which to measure nutritional status. He emphasized the importance of diet in war time and that, although the public health had so far been maintained, a watch must be kept. An immense social experiment was in progress.

Such developments as the milk-in-schools scheme, the drive for extension of school meals, and the establishment of canteens in factories, and of British Restaurants, are advances in preventive medicine directed towards maintaining a satisfactory nutritional standard in the community. Too much emphasis has hitherto been laid on disease and the cure of 
disease and it is essential that the bias should be transferred to the establishment and maintenance of health. It is in the new concept of positive health that the science of nutrition can contribute so much and, as this concept becomes more and more appreciated, so will that science assume even greater importance. The influence of good nutrition on the incidence of disease generally is well known, whilst it is of particular significance in the incidence of social diseases such as tuberculosis. The new orientation towards social medicine becomes, therefore, a matter of the first importance and this Society can contribute considerably towards that object. I wish it every success in its efforts.

\section{Standards and their Implications}

\section{Sir John Orr (Rowett Research Institute, Bucksburn, Aberdeen)}

During the 19th century dietary requirements were calculated solely in terms of the amount of energy needed for the maintenance of heat and the performance of muscular work, and of the amount of protein needed for wear and tear in adults and for constructive growth in children. It was assumed that, if people had sufficient food for these purposes, the needs of the body for food would be met. Early in the present century, physiologists discovered that natural foodstuffs contained vitamins which are essential for health, and it was found that some commonly occurring diseases were due to a lack of these vitamins in the diet. This led to a re-examination of the requirement for minerals, the amounts of which had previously been underestimated and to a newer knowledge of nutrition which led to the setting up of a new dietary standard which provided, in addition to calories and protein, sufficient amounts of vitamins and minerals to maintain health.

One of the first statements on -standards, drawn up on modern lines, was published by the Committee on Nutrition of the British Medical Association (1933). It was a report on the kind of diet which would maintain working efficiency at minimum cost. In the same year the Stiebeling standard was published in Washington, stating the standard in terms of dietary constituents and also of the foodstuffs which would supply the stated amounts of all the constituents (Stiebeling, 1933). In 1935 an International Committee, appointed by the League of Nations, drew up a standard for mothers and children (League of Nations Health Committee. Technical Commission, 1936). In 1940 the Canadian Medical Association suggested diets to meet the requirements for health for families of different sizes (Canad. Med. Assoc., 1940). These standards were provisional estimates to be adjusted in the light of further clinical and experimental findings. The "Washington yardstick," which is a report of the Committee on Food and Nutrition of the U.S.A. National Research Council (1941), recommending daily allowances for specific nutrients including riboflavin and nicotinic acid, is fundamentally an extension in the light of the most modern knowledge of its precursors, and is to be regarded as the latest authoritative word on requirements. It is this standard (Table 1) that will be discussed in detail by the other speakers today*.

* This standard is referred to frequently by speakers at this and the following meeting and will be referred to for brevity throughout as the N.R.C. standard.

FoL. 1, 1844] 


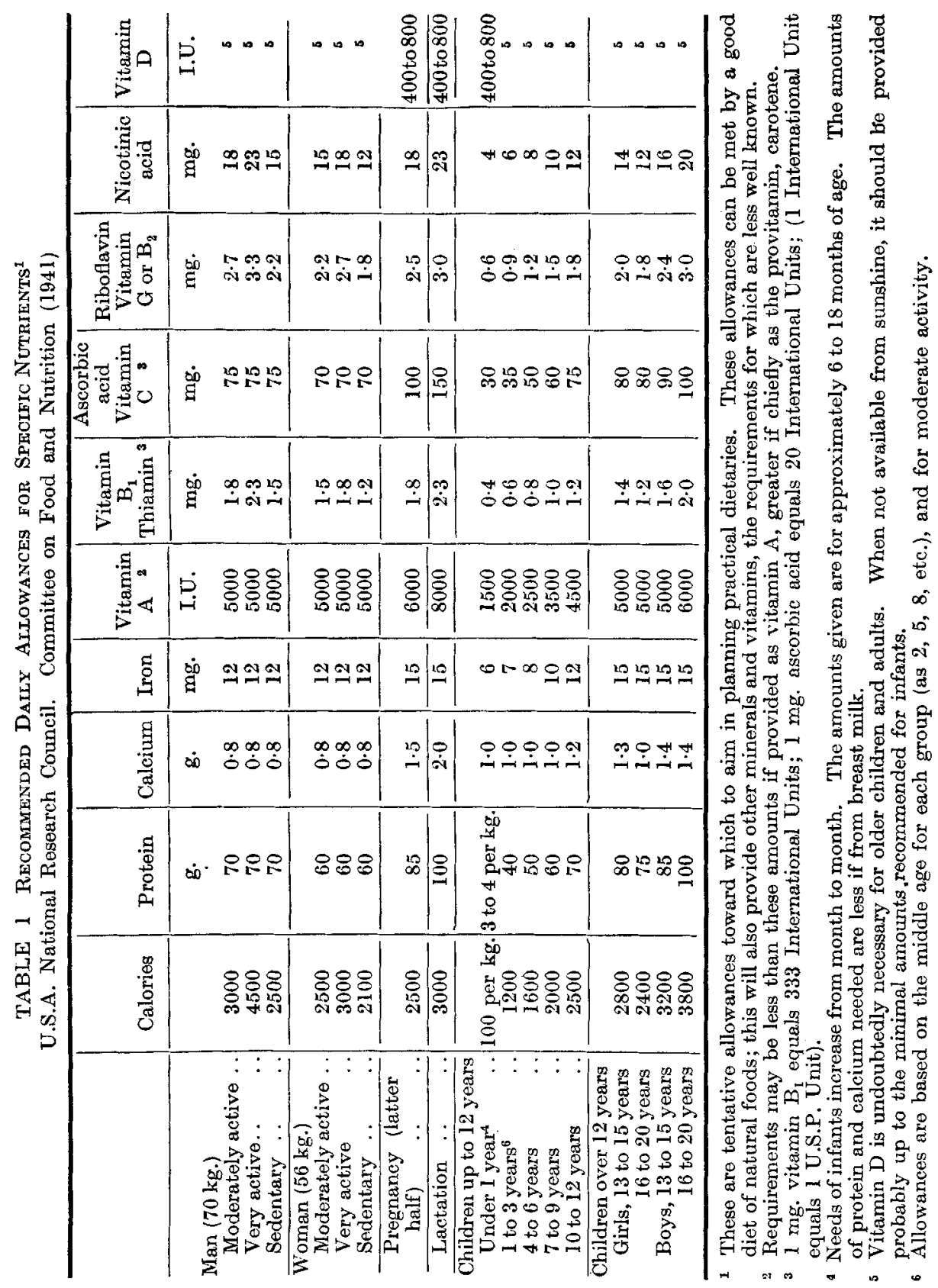


Two points should be noted: These statements of requirements, while differing in slight detail, are all in close agreement and these new standards have been approved by authoritative bodies. The League of Nations standard has been approved by the Ministry of Health, the Medical Research Council, and similar bodies in other countries. The recommendation of the Committee on Food and Nutrition is approved by the Government of the United States and has been adopted with minor modifications to suit local conditions in Canada, S. Africa, Australia and elsewhere.

Clinical investigations in the United Kingdom and other countries have shown that the highest known levels of health and physical fitness are enjoyed by people whose diet conforms to the modern standard and that the further the diet falls from the standard, the more levels of health and physical fitness also deteriorate (Orr, 1937). It is further evident from a mass of data from many countries that low grade physical fitness and low grade food intake are common, even in the wealthiest countries where the standard of living is highest. It is a commonplace for dietary surveys to show that the diet of one-third to one-half of the population is below the standard adopted and that standard is by no means always an optimum. If these facts hold for the U.S.A., the United Kingdom, Canada, S. Africa and Australia, conditions are certainly not better in China, India, the Balkans, or Spain, where even on a calorie basis the food supplies are inadequate for the needs of the population.

The standard of the "Washington yardstick" is practical because the average diet of the families that make up about two-thirds of the British people is, on the whole, adequate for health. The question then resolves itself into bringing the diet of the poorest third of our population at least up to the level enjoyed by the others. What effect is this likely to have on the health and physique of the poorest third?

Feeding experiments have shown what improvement of diet can do. The most striking results have been reported from the physical development depots of army recruits at Canterbury (Capon, 1937; Crawford, 1939) and from the Selective Service experiments on young men rejected for military service in the United States. A 9 weeks' programme of healthy recreation and good food resulted in 87 per cent. of the men being sufficiently improved to meet army requirements. Similar evidence comes from the supplementary feeding of schoolchildren under the Milk Nutrition Committee (1938).

If, then, a food policy based on human needs is adopted, the first task will be to provide the necessary additional foods. Estimates of the additional amounts of the protective foodstuffs needed to bring the diet of the whole population up to the health level have been made for the United States. To feed the whole population adequately on a free choice basis, production would have to be increased by the following percentages: butter 15, milk 20, eggs 35 , tomatoes and citrus fruits 70 and green leafy vegetables 100 (Stiebeling, 1939). Comparable increases would be required for the United Kingdom, where such detailed estimates have not yet been made, but where, for instance, the milk production would need to be doubled to bring consumption up to the level recommended by the Advisory Committee on Nutrition appointed by the Government in 1935 (Ministry of Health. Advisory Committee on Nutrition, 1937).

voL. 1,1944$]$ 
In addition to these major problems, there remain others of a subsidiary nature. The first of these is the conservation and preservation of food to ensure that the winter diet shall be as good as that available in the summer and the second is the education of the consuming public in food values and the dietary requirements at various ages. The demonstrations and newspaper articles sponsored by the Ministry of Food should be maintained after the war and the activities of the Consumers' Council of the U.S.A. should be adapted to suit British conditions. There are the best of reasons for hoping that if the standard of living, with related food standards, of Scotland were as high as in New Zealand, the effect on infant mortality and on expectation of life would become equally good.

\section{References}

British Medical Association. Committee on Nutrition (1933). Brit. med. J. Suppl, Nov. 25.

Canadian Medical Association (1940). Food for Health in Peace and War. What Canadian Doctors Suggest for Wholesome Meals at Low Cost.

Capon, P. J. (1937). J. R. Army med. Cps, 68, 293.

Crawford, J. A. (1939). J. R. Army med. Cps, 73, 1.

League of Nations Health Committee. Technical Commission (1936). Quart. Bull. Hlth Org. L.o.N. 5, 391.

Milk Nutrition Committee (1938). Milk and Nutrition, Part II. Reading: Nat. Inst. Res. Dairying.

Ministry of Health. Advisory Committee on Nutrition (1937).' First Report. London: H.M.S.O.

Orr, J. B. (1937). Food, Health and Income. 2nd ed. London: Macmillan.

Stiebeling, H. K. (1933). Misc. Publ. U.S. Dep. Agric. no. 183.

Stiebeling, H. K. (1939). Yearb. U.S. Dep. Agric. p. 380.

U.S.A. National Research Council. Committee on Food and Nutrition (1941). J. Amer. med. Ass. 116, 2601.

\section{Standards for Proximate Principles}

Dr. D. P. Cuthbertson (Department of Physiology University of Glasgow)

Present day diets throughout the world can be roughly classified under three main headings within which there is considerable overlapping: those of mainly animal origin, those of mainly vegetable origin, and those of mixed origin. Their world distribution is shown in Table 1 (Cuthbertson, 1940).

TABLE 1

Wordi Classification of Diets

\begin{tabular}{|c|c|c|c|c|}
\hline & & Mainly animal & Mainly vegetable & Mixed \\
\hline & & $\begin{array}{l}\text { Circumpolar } \\
\text { peoples, Eskimo, } \\
\text { Lapp, Samoyed, } \\
\text { etc. } \\
\text { Pustoral nomads, } \\
\text { Khirghiz, Masai, } \\
\text { Somali, etc. }\end{array}$ & $\begin{array}{l}\text { Indigenous } \\
\text { populations of } \\
\text { India, China, } \\
\text { inland regions of } \\
\text { East Indian } \\
\text { Archipelago, } \\
\text { Africa, etc. }\end{array}$ & $\begin{array}{l}\text { Europe and } \\
\text { European settle- } \\
\text { ments, Dominions } \\
\text { and America, } \\
\text { certain Asiatic } \\
\text { and African } \\
\text { peoples }\end{array}$ \\
\hline $\begin{array}{l}\text { Percentage } \\
\text { energy } \\
\text { derived } \\
\text { from: }\end{array}$ & $\begin{array}{l}\text { Protein } \\
\text { Fat .. } \\
\text { Carbohydrate }\end{array}$ & $\begin{array}{l}40^{*} \\
50^{*} \\
10^{*}\end{array}$ & $\begin{array}{l}12 \\
10 \\
78\end{array}$ & $\begin{array}{l}11 \\
33 \\
56\end{array}$ \\
\hline
\end{tabular}

* Data for Eskimo and Masai only. 
Such a survey shows that man can adjust himself to widely different levels of intake of protein, fat and carbohydrate if his calorie demands are met. No deleterious effects result from a diet of exclusively animal or vegetable origin provided the amino-acids are supplied in satisfactory combination and that all other nutrient essentials are present in adequate amounts.

For the purpose of the present note it is proposed to limit discussion to the dietary requirements of Europe and European settlements in America and the Dominions, and, in particular, to discuss the values laid down by the U.S.A. National Research Council (N.R.C. Standard, cf. p. 43).

Protein. Attempts to assess the standard requirement for adult maintenance can be divided into four main types:

(1) Observations of food actually eaten by individuals or groups.

(2) Measurements of nitrogen balance. To values so obtained it is customary to make an empirical addition as a safety factor.

(3) Estimates based on the minimum endogenous nitrogen expenditure, due account being taken of the biological value of the proteins with an addition as a margin for safety.

(4) Long term experiments with various low levels of intake of protein.

Measurements by the second method are in general based on metabolic periods of too short duration and the results have finally to be adjusted to fit more nearly the values found by the first method. The third method most probably underestimates requirement, particularly when judged in the light of recent work by Schoenheimer, Rittenberg and their colleagues (1939, 1942 and many intermediate publications), who studied the distribution of the isotope $\mathrm{N}^{15}$ within the body tissues after its ingestion. The fourth method entails impairment of health and general physiological efficiency and is, therefore, complicated by psychological and other difficulties. There remains the first method, which is certainly the one least likely to give a false answer, although it must be borne in mind that when individuals are under close observation, psychological factors may vitiate the results. It must be borne in mind, moreover, that it is possible that the association with protein of other known and perhaps unknown dietary essentials may induce consumption of protein in excess of the actual requirement. Further, it must be remembered that the mean value calculated from a dietary study of a family is the mean requirement of the family and not of any individual in it. On the other hand the members of a family tend to eat the same type of food, the total amount being conditioned by the calorie requirements (Evang and Hansen, 1939; Tigerstedt, 1916). The milk scheme for schools and special meals for children will tend to disturb this relationship.

When the energy derived from protein is expressed as a percentage of the total calories it is found that in temperate countries this value lies between 10 and 14 , and tends to remain constant in a given population for all types of workers with the exception of athletes in special training who in general select diets containing a high proportion of protein, especially of animal origin. In general, it may be said that whenever and wherever economic circumstances permit, man elects to raise his intake of animal protein to the region of 60 per cent. of the total protein intake.

voL. 1, 1944] 
The allowances of protein in some of the N.R.C. standards fall below 10 per cent. of the total calories and thus run contrary to established habit in this country. Some alteration is considered necessary to conform with dietary habits and this has been made in Table 2. It is emphasized that no real scientific evidence can be adduced in support of the values given in the table or of the correction which the speaker has made. It is believed that in the present state of our ignorance it is safer to rely on established custom; it may be that in this country protein has to constitute 10 to 12 per cent. of the total calories in order to form an optimum metabolizable mixture, or it may be that this proportion is necessary to allow for the protein requirements of the various members of the family, or it may be that, by maintaining this level, other associated dietary factors are most favourably supplied. It is held that during the latter half of pregnancy and lactation the protein intake might be maintained at a higher general level owing to the exceptional demands for protein in these conditions.

Reference to the requirements of children under 1 year has been omitted as so much, in the earlier months, depends on whether or not the child is breast fed. The requirements for older children can best be considered as they are laid down in Table 2 , in comparison with the calorie requirements.

Calories. The N.R.C. standards raise certain points that appear to require revision. (1) The surface area of the average employed man in these islands is less than that of a man of $70 \mathrm{~kg}$. A correction based on surface area has, therefore, been made for the moderately active and sedentary man. (2) It is considered that the value of 4500 Calories for the very active working man is probably too high and a reduced net value of 4200 Calories is given. (3) It is held that an addition should be made to the calorie requirement of the very active woman since her performance may fall not far short of 50 to 60 per cent. of that of her male counterpart.

It is essential that the calorie requirement should not be subject to legislative restriction unless a state of siege or famine should necessitate such a drastic step.

Fat. The variation throughout the world in the consumption of fat is greater than in that of protein and, in the second and third types of diet listed in Table 1, the constancy of intake shown by protein is not exhibited by fat.

Recently the question has been raised whether fat is an obligatory principle in the diet provided the fat soluble vitamins and essential unsaturated fatty acids are present. The answer would appear to be that it is not. Our customary intake does not appear to represent a requirement for fat as such, yet precedent has established its consumption to the extent of some 30 to 35 per cent. of the calories of food eaten in this country. In the absence of complete knowledge it is again safer to adhere to long established custom.

In the Netherlands East Indies fat consumption is very low and even where it can be augmented the daily intake is from 8 to $22 \mathrm{~g}$. Even in one of the best situated areas, with no economic bar to increasing fat consumption, it is not more than 5 to $10 \mathrm{~g}$. and yet health and nutritional condition appear to be good (Van Veen, 1941). Fat and protein together, or even separately, render the diet more appetizing, particularly in 
temperate and colder regions. Fat has the added advantage of compactness and of rendering hunger between meals less insistent.

In conclusion it is emphasized that although we do know something about calorie requirements, we have no accurate knowledge of the optimum requirements of protein and fat in the diet or of the proportions in which these should be derived from animal sources. It would appear safer to be guided by long established precedent, than by observations made in short period experiments, or by theoretical considerations.

\section{TABLE 2}

Comparison of American Allowances of Calories and Protein (N.R.C. Standards) with Values Revised to Suit Dietary Habits in the United KINGDOM

\begin{tabular}{|c|c|c|c|c|c|c|c|}
\hline & & \multicolumn{3}{|c|}{ American allowances } & \multicolumn{3}{|c|}{ Revised (net values) } \\
\hline & & Calories & $\begin{array}{l}\text { Pro- } \\
\text { tein } \\
\mathrm{g} .\end{array}$ & $\begin{array}{l}\text { Percent- } \\
\text { age of } \\
\text { cals. } \\
\text { derived } \\
\text { from } \\
\text { protein }\end{array}$ & Calories & $\begin{array}{l}\text { Pro- } \\
\text { tein } \\
\text { g. }\end{array}$ & $\begin{array}{l}\text { Percent- } \\
\text { age of } \\
\text { cals. } \\
\text { derived } \\
\text { from } \\
\text { protein }\end{array}$ \\
\hline $\begin{array}{l}\text { Man }(70 \mathrm{~kg} .) \\
\begin{array}{l}\text { Moderately active } \\
\text { Very active }\end{array} \text {. } \\
\text { Sedentary }\end{array}$ & $\begin{array}{l}\cdots \\
\cdots \\
\cdots\end{array}$ & $\begin{array}{l}3000 \\
4500 \\
2500\end{array}$ & $\begin{array}{l}70 \\
70 \\
70\end{array}$ & $\begin{array}{r}9 \cdot 6 \\
6 \cdot 4 \\
11 \cdot 5\end{array}$ & \begin{tabular}{|c|}
$\operatorname{Man}(61 \mathrm{~kg})$. \\
2900 \\
4200 \\
2400
\end{tabular} & $\begin{array}{r}75 \\
110 \\
65\end{array}$ & $\begin{array}{l}10 \cdot 6 \\
10 \cdot 7 \\
11 \cdot 1\end{array}$ \\
\hline $\begin{array}{l}\text { Woman (56 kg.) } \\
\text { Moderately active } \\
\begin{array}{ll}\text { Very active } & \ldots \\
\text { Sedentary } & .\end{array}\end{array}$ & $\begin{array}{l}\cdots \\
\cdots\end{array}$ & $\begin{array}{l}2500 \\
3000 \\
2100\end{array}$ & $\begin{array}{l}60 \\
60 \\
60\end{array}$ & $\begin{array}{r}9 \cdot 8 \\
8 \cdot 2 \\
11 \cdot 7\end{array}$ & $\begin{array}{l}2500 \\
3200 \\
2100\end{array}$ & $\begin{array}{l}65 \\
80 \\
55\end{array}$ & $\begin{array}{l}10 \cdot 7 \\
10 \cdot 3 \\
10 \cdot 7\end{array}$ \\
\hline Pregnancy (latter half) & & 2500 & 85 & $13 \cdot 9$ & 2500 & 75 & $12 \cdot 3$ \\
\hline Lactation & $\cdots$ & 3000 & 100 & $13 \cdot 7$ & 3000 & 95 & $13 \cdot 0$ \\
\hline 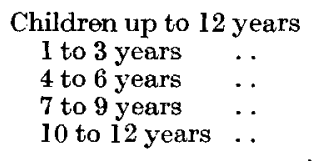 & $\begin{array}{l}\cdots \\
\cdots\end{array}$ & $\begin{array}{l}1200 \\
1600 \\
2000 \\
2500\end{array}$ & $\begin{array}{l}40 \\
50 \\
60 \\
70\end{array}$ & $\begin{array}{l}13 \cdot 7 \\
12 \cdot 8 \\
12 \cdot 3 \\
11 \cdot 5\end{array}$ & $\begin{array}{l}1200 \\
1600 \\
2000 \\
2500\end{array}$ & $\begin{array}{l}40 \\
50 \\
65 \\
80\end{array}$ & $\begin{array}{l}13 \cdot 7 \\
12 \cdot 8 \\
13 \cdot 3 \\
13 \cdot 1\end{array}$ \\
\hline $\begin{array}{r}\text { Children over } 12 \text { years } \\
\text { Girls, } 13 \text { to } 15 \text { years } \\
16 \text { to } 20 \text { years } \\
\text { Boys, } 13 \text { to } 15 \text { years } \\
16 \text { to } 20 \text { years }\end{array}$ & . & $\begin{array}{l}2800 \\
2400 \\
3200 \\
3800\end{array}$ & $\begin{array}{r}80 \\
75 \\
85 \\
100\end{array}$ & $\begin{array}{l}11 \cdot 7 \\
12 \cdot 8 \\
10 \cdot 9 \\
10 \cdot 8\end{array}$ & $\begin{array}{l}2800 \\
2400 \\
3200 \\
3800\end{array}$ & $\begin{array}{r}90 \\
70 \\
100 \\
110\end{array}$ & $\begin{array}{l}13 \cdot 2 \\
12 \cdot 0 \\
12 \cdot 8 \\
11 \cdot 9\end{array}$ \\
\hline
\end{tabular}

\section{REFERENCES}

Cuthbertson, D. P. (1940). Nutr. Abstr. Rev. 10, 1.

Evang, K. and Hansen, O. G. (1939). Acta med. scand. Suppl. 103.

Schoenheimer, R., Ratner, S. and Rittenberg, D. (1939). J. biol. Chem. 127, 333.

Schoenheimer, R., Ratner, S., Rittenberg, D. and Heidelberger, M. (1942). J. biol. Chem. 144, 541.

Tigerstedt, C. (1916). Skand. Arch. Physiol. 34, 151.

Van Veen, A. G. (1941). Natuurwet. Tijdschr. Ned.-Ind. 101, 33.

vor. 1, 1944] 


\section{The Adequacy of the Recommended Calcium and Iron Allowances}

\section{Dr. J. Duckworth (Rowett Research Institute, Bucksburn, Aberdeen)}

The two mineral constituents in which diets are most often judged to be deficient are calcium and iron. These are, therefore, the two for which standards are of most importance.

Calcium. The term requirement is difficult to define with precision. In terms of dietary calcium it can be described as the amount of calcium that will just meet the individual's daily needs for skeletal and soft tissues and cover the unavoidable losses in urine and faeces. Because of individual variations, particularly those arising in children growing at a more than average rate and with consistently greater than average daily depositions of calcium, the average daily intake should exceed average requirement by an amount sufficient to provide for special needs. If this extra quantity is termed the "margin of safety" then the term "allowance" can be taken to mean "average requirement plus margin of safety." The most satisfactory method of assessing the present allowances would be to compare them with accepted standards of requirement to see whether the margin of safety is adequate. Unfortunately there is as yet no agreement regarding the requirements of calcium at different ages.

In an attempt to assess requirement, Duckworth and Warnock (1942) adopted the following method: From the data of Venar and Todd (1933) on skeletal size in children, the amount of calcium deposited daily was estimated on the assumption that the dry matter of the skeleton contains 57 per cent. of inorganic matter which, in turn, contains 37.5 per cent. of calcium; a survey was then made of the calcium metabolism studies in the literature to determine average retentions of calcium at different levels of intake by children of different ages. Comparison of the amounts of calcium that would bc expected to be retained on the basis of the skeletal data with the amounts actually retained at different levels of intake showed that at each age the intake required was less than the amount recommended in the suggested N.R.C. standard seale of allowances. The differences were of the order of 200 to $300 \mathrm{mg}$. daily. Against this method of assessment can be brought the criticisms that it is probable that the material of Venar and Todd does not represent a cross section of present day children, and that the assumption that the skeleton contains 57 per cent. of inorganic matter is probably an overestimate for young rapidly growing children. These modifications are in opposite directions and would, therefore, offset each other, but to what extent cannot be said at the present time. In spite of the inadequacy of the data it is difficult to believe that future work will lead to marked alteration of the estimates of requirement and the margin of safety of 200 to $300 \mathrm{mg}$. daily should be ample to cover the special additional requirements of rapidly growing children and, except in extreme cases, those arising from attacks of illness.

The allowances for adults require little attention. Leitch's (1936-37; 1938) estimate of $10 \mathrm{mg}$ of calcium per $\mathrm{kg}$. bodyweight for women has been confirmed and extended to men (Mitchell, 1939). Adequate margins 
of safety are included in the N.R.C. standards, especially for women. Of allowances for pregnancy and lactation it can be said that the recommendations agree with the general consensus of opinion but the scarcity of information about factors involved in the building up of skeletal reserves of calcium during pregnancy to meet subsequent demands of lactation precludes a close analysis.

Iron. The allowances of iron recommended in the N.R.C. standard do not differ from those generally accepted. The adult male allowance is far greater than the requirement as judged by recent work. It is unlikely that common diets will fail to meet adult male requirements, at least in health.

The unduly wide margin of safety in the allowance recommended for males might, however, have a disturbing effect in an analysis of dietary survey data for families with an undue preponderance of adult males. In such a case where the family intake of iron was not high, overestimation of the requirement of the adult males would lead to the demonstration of a spurious deficiency in the diet of the rest of the family.

\section{REFERENCES}

Duckworth, J. and Warnock, G. M. (1942). Nutr. Abstr. Rev. 12, 167.

Leitch, I. (1936-37). Nutr. Abstr. Rev. 6, 553.

Leitch, I. (1938). Nutr. Abstr. Rev. 8, 1.

Mitchell, H. H. (1939). The Dietary Requirement of Calcium and its Significance. Paris: Hormann et Cie.

Venar, Y. and Todd, T. W. (1933). White House Conference on Child Health and Protection. Growth and Development of the Child, 2. p.93. New York: The Century Co.

\section{Standards for Vitamins}

\section{Surgeon Commander C. C. Ungley, R.N.V.R. (From a Naval Auxiliary Hospital)}

Assessments of needs for various vitamins are based largely on know: ledge of the amounts needed to prevent the earliest indications of deficiency, macroscopic, microscopic or biochemical. The evidence is derived from analogies with animal requirements, from composition of human diets in relation to the occurrence of deficiency states, from the dosage of vitamins sufficient to cure deficiency diseases, from vitamin excretion in relation to levels of intake, from the vitamin content of body fluids in relation to intake, and from experimental vitamin deficiency in man. A brief consideration of such evidence and of the factors governing individual requirements is necessary to a critical review of the N.R.C. standards.

Vitamin A. Vitamin A is probably a structural material rather than one concerned in chemical processes since needs are related more to bodyweight than to energy metabolism. More International Units must be allowed if they are derived from carotene, which is less readily utilized than preformed vitamin A. Absorption of vitamin A is aided by a diet rich in fats, especially unsaturated fats. Absorption of carotene is inhibited by liquid paraffin. Requirements are increased by intestinal disorders such as steatorrhoea, lack of bile in the intestine, liver diseases, hypothyroidism and infections.

voL. 1,1944$]$ 
In determining minimum requirements the difficulty has been the early detection of vitamin A deficiency. Visual adaptation to dim light is affected by many factors other than nutritional deficiency. Even the results of induced deficiency in man have been conflicting. Some workers find that reduction in the daily intake of vitamin A to 150 to 550 I.U. produces an almost immediate rise in visual threshold; others observe no such effect even after months of deficiency. Some individuals seem to be able for long periods to draw on bodily stores, which in others are inadequate or not readily mobilized. Skin lesions, pilo-sebaceous hyperkeratosis or phrynoderma, sometimes appear when there is no visual dysadaptation. Assessment of the amount of vitamin A required to prevent early xerosis of the conjunctiva, detectable by slit lamp and biomicroscope (Kruse, 1941) may soon be available. Determination of the vitamin A and carotene content of blood has helped little; a low level of vitamin $\mathrm{A}$ in the blood may mean deficient mobilization and not necessarily lack of stores.

A daily dose of 20 to 30 I.U. vitamin A per $\mathrm{kg}$. bodyweight will prevent hemeralopia in various mammals, including human infants, children and adults. Accordingly a man weighing $70 \mathrm{~kg}$. needs as a physiological minimum 1400 to 2000 I.U. vitamin A as the preformed vitamin or about twice that amount as carotene. In animals allowances well above the minimum permit increased storage and conduce to longevity. The N.R.C. standard of 5000 I.U. daily should suffice for optimum nutrition and adequate reserves while allowing for wide individual variations in requirement and utilization of vitamin $\mathrm{A}$ and carotene (Table 1 ).

TABLE 1

Levels of Vitamin A Intake in Retation to Bodily Health

\begin{tabular}{|c|c|c|c|}
\hline \multicolumn{2}{|c|}{ Intake per day, I.U. } & \multicolumn{2}{|c|}{ Signs and symptoms } \\
\hline \multicolumn{2}{|c|}{$\begin{array}{l}\text { per } 70 \mathrm{~kg} \text {. per kg. } \\
\text { bodyweight }\end{array}$} & Man & Animals \\
\hline 5000 & 70 & None & None \\
\hline 3500 to 1500 & 50 to 20 & Cures hemeralopia & None \\
\hline $\begin{array}{l}2000 \text { to } \\
1500\end{array}$ & $\begin{array}{c}30^{*} \text { to } \\
20^{*}\end{array}$ & $\begin{array}{l}\text { Prevents hemeralopia in in- } \\
\text { fants, children and adults }\end{array}$ & $\begin{array}{l}\text { Prevents hemeralopia; ani- } \\
\text { mals gain well and thrive } \\
\text { but need more for reserves } \\
\text { and longevity }\end{array}$ \\
\hline $\begin{array}{l}300 \text { to } \\
100\end{array}$ & $\begin{array}{l}4 \text { to } \\
1.5\end{array}$ & $\begin{array}{l}\text { Experimental hemeralopia } \\
\text { and skin lesions; slit lamp } \\
\text { findings questionable }\end{array}$ & Partial deficiency \\
\hline 0 to ? & 0 to ? & Gross lesions & Gross lesions \\
\hline
\end{tabular}

* As vitamin A or twice this number of I.U. as carotene.

Stores of vitamin $\mathrm{A}$ in the liver are low at birth, but increase rapidly in well fed infants; premature and artificially fed babies need special attention. Amounts of vitamin A to prevent hemeralopia are, per $\mathrm{kg}$. bodyweight, no greater than for adults, 135 to 300 I.U. sufficing for 
infants, and 500 to 900 I.U. for children aged 6 to 12 years. Lewis and Haig $(1939 ; 1940)$ found that children's diets usually contained fully twelve times the minimum requirement and that visual dysadaptation was rare; skin infections in infancy were no indication of vitamin $A$ deficiency. N.R.C. standards are well above amounts needed to prevent dysadaptation but not more than are usually contained in the diets of well fed children. Since the average daily yield of vitamin $A$ in human milk may be 3000 I.U. (With and Friderichsen, 1939) the N.R.C. standard of 8000 I.U. for a woman during lactation is not excessive. Pregnancy does not appreciably increase requirements and 6000 I.U. daily in the latter half of pregnancy, as suggested by the N.R.C. is probably sufficient.

Vitamin $B_{1}$. Vitamin $B_{1}$ is concerned in carbohydrate metabolism, and needs are proportional to the non-fat calories in the diet. Fats and choline, and perhaps also riboflavin, spare vitamin $B_{1}$. Refined cereals, sugar and alcohol, increase requirements from other sources by providing calories without vitamin $B_{1}$. Bodyweight is important only in that it influences calorie intake. Needs for vitamin $B_{1}$, which is not stored to any extent, are increased by metabolic activity associated with growth, pregnancy, fever, exercise and hyperthyroidism, also by diuresis and lactation. Factors influencing absorption are important; beriberi in this country is usually secondary to gastro-intestinal disease, hyperemesis gravidarum or chronic alcoholism.

The borderline between sufficiency and deficiency is ill defined. Signs include anorexia, tenderness of the calves, tachycardia, oedema, changes in blood pressure occurring while at rest, after exercise and after administration of adrenaline and of pituitrin, cardiac enlargement and electrocardiographic changes. Determination of the increase in pyruvic acid in blood and urine helps little in diagnosing slight deficiency. The amount of vitamin $B_{1}$ excreted in the urine reflects immediate past intake of the vitamin; the value for vitamin $\mathrm{B}_{1}$ in the blood is more useful as a guide to the nutritional state. Beriberi has been observed clinically and produced experimentally when intake of vitamin $B_{1}$ was $0.5 \mathrm{mg}$. or less per 3000 Calories (Table 2). The physiological minimum is usually given as 0.75 to $0.9 \mathrm{mg}$. The N.R.C. standard of $1.8 \mathrm{mg}$. leaves a wide margin of safety. Beriberi often clears up rapidly after administration of a total of only 2 or $3 \mathrm{mg}$. In experimental vitamin $B_{1}$ deficiency there is no added benefit with intakes above 1.5 to $3 \mathrm{mg}$, per 3000 Calories (Williams and Mason, 1941).

During growth the vitamin $\mathrm{B}_{1}$ requirements per 1000 Calories are higher than in adults. Breast fed infants of mothers deficient in vitamin $B_{1}$ may develop beriberi, the milk being actually toxic (Fehily, 1940). In children, increased weight gains follow increased intake of vitamin $B_{1}$. In children aged 4 to 7 years the highest retention of vitamin $B_{1}$ occurred with daily intakes of 1 to $1.2 \mathrm{mg}$. vitamin $B_{1}$ per 1600 Calories. The N.R.C. standard for this age is $0.8 \mathrm{mg}$.

Vitamin $B_{1}$ requirements are increased, perhaps trebled, in pregnancy and lactation. The allowance suggested by Cowgill (1938) is equivalent to about $1.5 \mathrm{mg}$. The N.R.C. standards are $1.5 \mathrm{mg}$. for a non-pregnant woman, $1.8 \mathrm{mg}$. during pregnancy and $2.3 \mathrm{mg}$. during lactation. Information regarding requirements is at present too scanty to permit criticism of these standards.

voL. 1, 1944] 
TABLE 2

Levels of Vitamin B 1 Intake in Adults in Relation to Bodily Health

\begin{tabular}{|c|c|c|}
\hline Intake per day & & \\
\hline $\begin{array}{l}\text { mg. per } \\
3000 \text { Calories }\end{array}$ & Remarks & Author \\
\hline up to $4 \cdot 0$ & True optimum? & Williams, 1938 \\
\hline 3.0 to 1.5 & $\begin{array}{l}\text { Cures beriberi and induced } \\
\text { vitamin } B_{1} \text { deficiency }\end{array}$ & Williams and Mason, 1941 \\
\hline $1 \cdot 8$ & $\begin{array}{l}\text { Desirable intake } \\
\text { Recommended allowance }\end{array}$ & $\begin{array}{l}\text { Baker and Wright, } 1937 \\
\text { N.R.C. }\end{array}$ \\
\hline $\begin{array}{l}0 \cdot 9 \\
0 \cdot 85 \\
0 \cdot 75\end{array}$ & $\begin{array}{l}\text { Physiological minimum } \\
\text { Minimum for } 70 \mathrm{~kg} \text {. } \\
\text { Borderline values }\end{array}$ & $\begin{array}{l}\text { Baker and Wright, } 1937 \\
\text { Cowgill, } 1938 \\
\text { Williams and Spies, } 1938\end{array}$ \\
\hline $\begin{array}{l}0.4 \text { to } 0.5 \\
0.55 \text { or less }\end{array}$ & $\begin{array}{l}\text { Induced vitamin } \mathrm{B}_{1} \text { deficiency } \\
\text { Grave risk of beriberi }\end{array}$ & $\begin{array}{l}\text { Williams and Mason, } 1941 \\
\text { Joliffe, Goodhart, Gennis and } \\
\text { Cline, } 1939 \\
\text { Van Veen, } 1935\end{array}$ \\
\hline
\end{tabular}

Riboflavin. Needs for riboflavin, which is concerned with cell respiration, are related to bodyweight, food intake, growth and metabolic activity (Tables 3 and 4). Deficiency produces lesions of the cornea,

TABLE 3

Levels of Riboflavin Intake in Adults in Relation to Bodily Health

\begin{tabular}{|c|c|c|c|}
\hline \multicolumn{2}{|c|}{ Intake per day } & \multirow[b]{2}{*}{ Remarks } & \multirow[b]{2}{*}{ Author } \\
\hline mg. & $\begin{array}{c}\text { Bourquin } \\
\text { Sherman } \\
\text { units }\end{array}$ & & \\
\hline 5 to 15 & - & Curative for eye lesions & $\begin{array}{l}\text { Sydenstricker, Kelly and } \\
\text { Weaver, 1941 }\end{array}$ \\
\hline $3 \cdot 0$ & - & $\begin{array}{l}\text { Estimated requiremonts based } \\
\text { on storage and excretion }\end{array}$ & $\begin{array}{l}\text { Sebrell, Butler, Wooley and } \\
\text { Isbell, } 1941\end{array}$ \\
\hline 2 to 3 & $\ldots$ & & $\underset{\text { Hogan) }}{\text { Emmerie, } 1936 \text { (cited by }}$ \\
\hline $1 \cdot 2$ to $3^{*}$ & 600 & Minimum requirement & Rose, 1937; Stiebeling, 1937 \\
\hline 0 to ? & - & $\begin{array}{l}\text { Ocular lesions. Mouth lesions. } \\
\text { Skin lesions. Stunted growth }\end{array}$ & \\
\hline
\end{tabular}

* Estimated equivalent in mg. riboflavin, one Bourquin Sherman unit of vitamin $G$ being taken as equal to 2 to $5 \mu \mathrm{g}$. riboflavin.

lips, tongue and skin of the face. Early vascularization of the cornea is visible by slit lamp and biomicroscope (Kruse, Sydenstricker, Sebrell and Cleckley, 1940), but similar vascularization may occur from other causes. Riboflavin in doses of 5 to $15 \mathrm{mg}$. daily or of $3 \mathrm{mg}$. for children, cures eye 
lesions. Storage and excretion experiments suggest that healthy adults need 2 to $3 \mathrm{mg}$. daily. Children's requirements have been gauged in Bourquin Sherman units (Rose, 1937; Stiebeling, 1937); if one such unit equals 2 to $5 \mu \mathrm{g}$. of riboflavin the suggested minimum needs for children are 0.8 to $2.7 \mathrm{mg}$. Data may soon be available as to the minimum amounts needed to prevent early vascularization of the cornea. Without such evidence it is difficult to criticize the N.R.C. standards.

TABLE 4

Levels of Riboflayin Intake in Children in Relation to Bodily Health

\begin{tabular}{|c|c|c|c|c|}
\hline \multirow[b]{2}{*}{$\begin{array}{l}\text { Age group } \\
\text { years }\end{array}$} & \multicolumn{2}{|c|}{ Intake per day } & \multirow[b]{2}{*}{ Remarks } & \multirow[b]{2}{*}{ Author } \\
\hline & mg. & $\begin{array}{c}\text { Bourquin } \\
\text { Sherman } \\
\text { units }\end{array}$ & & \\
\hline 0 to 10 & 0.8 to $2 \cdot 0^{*}$ & 400 & $\begin{array}{l}400 \text { units at least, or } 20 \text { units } \\
\text { per } 100 \text { Calorics, if more } \\
\text { than } 2000 \text { Calories con- } \\
\text { sumed }\end{array}$ & $\operatorname{Ros} \theta, 1937$ \\
\hline $\begin{array}{l}0 \text { to } 6 \text { Boys } \\
0 \text { to } 7 \text { Girls } \\
7 \text { to } 10 \text { Boys } \\
8 \text { to } 13 \text { Girls } \\
\text { Older children } \\
\text { and adults }\end{array}$ & $\begin{array}{l}0.9 \text { to } 2 \cdot 3^{*} \\
1 \cdot 1 \text { to } 2 \cdot 7^{*} \\
1 \cdot 2 \text { to } 3 \cdot 0^{*}\end{array}$ & $\begin{array}{l}450 \\
540 \\
600\end{array}$ & Minimum requirements & $\begin{array}{l}\text { Stiebeling, } \\
1937\end{array}$ \\
\hline Children & $3 \cdot 0$ & - & Curative for eye lesions & $\begin{array}{l}\text { Spies, Bean, } \\
\text { Vilter and } \\
\text { Huff, } 1941\end{array}$ \\
\hline
\end{tabular}

* See footnote to Table 3 .

Nicotinic Acid. Requirements for nicotinic acid, constituent of cozymase, are probably related to bodyweight, food intake, metabolic rate, and gastro-intestinal absorption. Needs are likely to be greater with exercise, growth, pregnancy and lactation. Chemical and biological methods have not yet established reliable estimates of intake, storage or excretion; detection of early deficiency is difficult. Pellagra in this country is mostly secondary to gastro-intestinal disease. Recent investigations (Ungley and Horton, 1943) do not support the suggestion that Vincent's disease is commonly related to nicotinic acid deficiency. Datis are insufficient to permit criticism of N.R.C. standards.

Ascorbic Acid. Ascorbic acid, concerned in the integrity of intercellular cement substances, is a powerful reducing agent. Needs are related less to bodyweight than to metabolic activity, being much higher per kg. bodyweight in children than in adults. How far requirements are increased by hard work, fever, and hyperthyroidism is uncertain. Scurvy is seen chiefly in elderly people living alone; allowances for the aged should not be ungenerous. Persons accustomed to a low intake utilize the substance economically, perhaps even resynthesizing some of it. Those accustomed to high intake not only excrete it but actually use more, perhaps burning it like carbohydrate.

voL. 1,1944$]$ 
Various levels of vitamin $\mathrm{C}$ nutrition are recognized:

(1) A state of saturation, as indicated in the adult by the prompt excretion of a large part of an oral test dose of $700 \mathrm{mg}$., is associated with plasma ascorbic acid values of about $1 \mathrm{mg}$. per $100 \mathrm{ml}$. To maintain saturation an intake of at least $100 \mathrm{mg}$. daily is needed. Many healthy persons seldom attain, much less maintain, a state of saturation, which some authors even designate abnormal. Szent-Györgyi (1938) points out, however, that although with a dose of 1.5 to $2 \mathrm{mg}$. daily a laboratory guineapig may be apparently healthy, larger doses protect it against diphtheria and other toxins, and that in natural surroundings the animal consumes 20 to $40 \mathrm{mg}$. a day and is thereby saturated.

(2) A state of unsaturation without symptoms or signs of vitamin C deficiency. This intermediate level of vitamin $\mathrm{C}$ nutrition is compatible with perfect health, and should not be labelled sub-clinical scurvy or hypovitaminosis $\mathrm{C}$.

(3) True sub-scurvy. At this nutritional level there are microscopic lesions, at least in animals and, in man, symptoms such as lassitude, pains in the limbs and follicular hyperkeratosis, which can be abolished by giving ascorbic acid. At this stage wound healing may be defective. Soreness and bleeding of the gums are often wrongly labelled subscorbutic. In 51 cases we (Ungley and Horton, 1943) found the incidence of unsaturation and of a low intake of ascorbic acid no greater than in healthy controls. There was no clinical evidence of scurvy or subscurvy. Local causes such as infection and calculus were sufficient to account for the gingivitis, and ascorbic acid was therapeutically ineffective. For the detection of sub-scurvy capillary resistance and intradermal dye tests are unreliable. Radiography of long bones is useful only in children but X-ray photographs of teeth may prove useful even in adults. Estimation of ascorbic acid values in plasma and of degree of saturation may indicate that the past intake of ascorbic acid has been low, but cannot establish that the subject is any the worse for this. Estimation of the level of ascorbic acid in the white cell platelet layer, which in a study of experimental human scurvy fell to zero a short time before clinical signs of deficiency appeared, might be helpful (Crandon, Lund and Dill, 1940).

(4) Frank scurvy. This usually develops after 5 or 6 months of a diet devoid of vitamin C. Subcutaneous haemorrhages appear round the hair follicles and later become general. The gums are not necessarily affected.

If Zilva (1941) is right in the analogy he draws between the requirements of man and the guineapig, a daily dose of $1 \mathrm{or} 2 \mathrm{mg}$. would prevent gross clinical scurvy in human adults, one of 3 or $4 \mathrm{mg}$. would prevent even microscopic lesions, and one of 10 to $15 \mathrm{mg}$. would produce slight but significant storage of ascorbic acid in the tissues. Zilva found that in human adults urinary output became stabilized at a daily intake of 30 to $40 \mathrm{mg}$., which he regarded as sufficient for tissue saturation. Fox, Dangerfield, Gottlich, Jokl and Suzman (1940) showed that $15 \mathrm{mg}$. of ascorbic acid daily protected South African natives from scurvy and kept them in good health. As a safe minimum 30 to $40 \mathrm{mg}$. was suggested. In my experience (unpublished) $50 \mathrm{mg}$. a day rapidly cures scurvy in adults, and their maintenance requirements are not likely to be more than this. To maintain saturation, however, an intake of at least $100 \mathrm{mg}$. is 
needed. The N.R.C. standard of $75 \mathrm{mg}$. a day is less than this but should suffice for health and leave a considerable margin (Table 5).

TABLE 5

Levels of Ascorbic Acid Intake in Relation to Bodily Health

\begin{tabular}{|c|c|c|c|}
\hline Intake per day & $\begin{array}{c}\text { Plasma } \\
\text { ascorbic }\end{array}$ & & \\
\hline $\begin{array}{l}\text { mg. per } \\
70 \mathrm{~kg} .\end{array}$ & $\begin{array}{l}\text { mg. per } \\
100 \mathrm{ml} .\end{array}$ & $\begin{array}{l}\text { test dose } \\
\text { of } 700 \mathrm{mg} \text {. }\end{array}$ & Remarks \\
\hline 100 or more & 1.0 or more & Saturated & Luxus requirement \\
\hline 75 & - & $\begin{array}{l}\text { Slightly } \\
\text { unsaturated }\end{array}$ & Allowance recommended by N.R.C. \\
\hline 50 & - & Unsaturated & Cures adult scurvy \\
\hline 30 & - & Unsaturated & $\begin{array}{l}\text { Maximum tissue concentration may be } \\
\text { attained with } 30 \text { to } 40 \mathrm{mg} \text {. (Zilva, } \\
\text { 1941) }\end{array}$ \\
\hline 15 & 0 to $0.3^{*}$ & Unsaturated & $\begin{array}{l}\text { Protects against scurvy and allows good } \\
\text { health (Fox, Dangerfield, Gottlich, } \\
\text { Jokl and Suzman, 1940) }\end{array}$ \\
\hline 0 to $? 4$ & 0 to $0 \cdot 3 \dagger$ & Unsaturated & Lassitude. Hyperkeratosis. Frank scurvy \\
\hline
\end{tabular}

* Values below $0.1 \mathrm{mg}$. per $100 \mathrm{ml}$. correspond to sustained intakes of 5 to $20 \mathrm{mg}$. (Bryan, Turner, Huenemann and Lotwin, 1941).

$\uparrow$ May be none in white cell platelet layer.

Plasma ascorbic acid values in the newborn are usually at or near the saturation level even if the mother herself is unsaturated. Breast fed infants of well nourished mothers receive 20 to $50 \mathrm{mg}$. daily and are thereby protected from depletion. In artificially fed infants the plasma values tend to fall rapidly after 10 days and those dying when a few months old may show histological evidence of scurvy. Supplements to ensure an intake of at least $20 \mathrm{mg}$, a day should begin within two weeks of birth. In breast fed infants, too, it is more economical to give supplements to the child than to the mother.

The metabolic needs of growing tissues and the possible role of ascorbic acid in combating diphtheria and other bacterial toxins are strong reasons for maintaining saturation in childhood. The saturation requirements of children, like those of infants, are high in proportion to bodyweight, probably 6.4 to $7.5 \mathrm{mg}$. per $\mathrm{kg}$. compared with 1.7 to 1.9 for adults. The N.R.C. standards are no more than adequate to meet these requirements.

Although well below saturation requirements the N.R.C. standard of $100 \mathrm{mg}$. will perhaps suffice for increased metabolism and placental and foetal storage in late pregnancy. Nursing mothers probably need $150 \mathrm{mg}$. daily if they are to yield 20 to $50 \mathrm{mg}$. in milk.

Vitamin $D$. Vitamin D or its equivalent in ultraviolet irradiation is necessary for proper utilization of calcium and phosphorus. Consideration of requirements presupposes an adequate intake of these minerals, vor. 1,1944$]$ 
the availability and utilization of which are affected by other dietary factors such as the phytin of cereals and the acid base balance, and by parathyroid and thyroid activity. It is possible that vitamin $\mathrm{D}_{2}$ may be slightly less potent for human subjects than vitamin $\mathrm{D}_{3}$. The mode of administration is important; intestinal absorption of the vitamin from oily concentrates may be less efficient than from high grade cod liver oil but low grade cod liver oil is too bulky. Enough vitamin D can be added to milk but irradiation of milk seldom raises the value to more than I 35 I.U. per quart. Single massive injections of calciferol once or twice a year have proved successful in preventing rickets. The less the exposure of children's skins to the vitamin D producing effects of sunlight, the greater the need for giving vitamin $\mathrm{D}$ in other ways.

Full term infants receiving sufficient calcium and phosphorus and 135 units of vitamin D daily escape rickets, the blood values for calcium and phosphorus falling within the lower normal range; a daily dose of 300 to 400 I.U. permits excellent dentition, optimum retention of calcium and phosphorus, and blood values for calcium and phosphorus at the upper normal levels. The maximum effect on growth is observed with 300 to $600 \mathrm{I}$.U. daily. The safe upper level of dosage for infants is 1200 to 1500 I.U.; if the dose is more than 1800 I.U. daily, growth rate and retention of calcium and phosphorus may be depressed. Breast fed infants usually require less vitamin $D$ than artificially fed babies but requirements vary and allowances should be the same. Premature infants require twice as much vitamin $D$ as full term babies because of differences in the stage of development and in the growth rate (Table 6).

TABLE 6

Levels of Vitamin D Intake in Infants in Relation to Bodily Health

\begin{tabular}{|c|c|c|c|c|}
\hline Intake per day & & & $\mathrm{Ca}$ and $\mathrm{P}$ & \\
\hline I.U. & Bones & Dentition & retention & rato \\
\hline 1800 or more & 一 & - & $\begin{array}{l}\text { Retention may bo } \\
\text { decreased }\end{array}$ & $\begin{array}{l}\text { May be de- } \\
\text { creased }\end{array}$ \\
\hline 600 to 800 & \multicolumn{4}{|c|}{ Optimum requirement for premature infants } \\
\hline 300 to 600 & Normal & Normal & $\begin{array}{l}\text { Upper normal } \\
\text { levels }\end{array}$ & Maximum \\
\hline 300 to 400 & $\begin{array}{l}\text { Prevents rickets in } \\
\text { full term and pre- } \\
\text { mature infants }\end{array}$ & Normal & $\begin{array}{l}\text { Upper normal } \\
\text { levels }\end{array}$ & \\
\hline 135 & $\begin{array}{l}\text { Prevents rickets in } \\
\text { full term infants }\end{array}$ & $?$ & $\begin{array}{l}\text { Lower normal } \\
\text { levels }\end{array}$ & Subnormal \\
\hline 0 to ? & Rickets & Poor & $\begin{array}{l}\text { Retention may be } \\
\text { low }\end{array}$ & Subnormal \\
\hline
\end{tabular}

Note. Artificially fed infants recuiro more than breast fed babies. Premature babies require twice as much as full term infants.

In children and adolescents a daily supply of 300 to 400 I.U. vitamin D seems to permit ample retention of calcium and phosphorus, of which there must be sufficient in the diet. Optimum requirements for adults 
are unknown. Osteoporosis in the elderly may result from prolonged deficiency of calcium and of sunlight or vitamin D. Requirements are increased in pregnancy but the optimum is unknown. Needs are heavy in lactation; an intake of $800 \mathrm{I}$.U. daily is suggested.

\section{REFERENCES}

For references up to 1937-1938 see American Medical Association [Ed.] (1939). The Vitamins. Chicago: American Medical Association. (A symposium of articles reprinted from $J$. Amer. med. Ass.)

Bryan, A. H., Turner, D. F., Huenemann, R. L. and Lotwin, G. (1941). Amer. J. med. Sci. 202, 77.

Crandon, J. H., Lund, C. C. and Dill, D. B. (1940). New Engl. J. Med. 223, 353.

Fehily, L. (1940). Caduceus, 19, 78.

Fox, F. W., Dangerfield, L. F,, Gottlich, S. F., Yokl, E. and Suzman, H. (1940). Proc. Transv. Mine med. Offrs' Ass. 19, 249;267; 289;292; 301.

Jolliffe, N., Goodhart, R., Gennis, J. and Cline, J. K. (1939). Amer. J. med. Sci. $198,198$.

Kruse, H. D. (1941). Milbank Mem. F'd quart. Bull. 19, 207.

Kruse, H. D., Sydenstricker, V. P., Sebrell, W. H. and Cleckley, H. M. (1940). Publ. Hlth Rep., Wash. 55, 157.

Lewis, J. M. and Haig, (. (I939). J. Pediat. 15, 812.

Lewis, .T. M. and Haig, C. (1940). J. Pediat. 16, 285.

Sebrell, W. H., Butler, R. F., Wooley, J. G. and Isbell, H. (1941). Publ. Hlth Rep., Wash., 56, 510.

Spies, T. D., Bean, W. B., Vilter, R. W. and Huff, A. E. (1941). Amer'. J. med. Sci. 200, 697 .

Sydenstricker, V. P., Kelly, A. R. and Weaver, J. W. (1941). Sth. med. J., Birmingham, Ala., 34, 165.

Ingley, C. C. and Horton, J. F. (1943). Lancet, 244, 397.

Williams, R. D. and Mason, H..L. (1941). Proc. Mayo Clin. 16, 433.

With, T. K. and Friderichsen, C. (1939). Ugeskr. Laeger, 101, 915.

Zilva, S. S. (1941), J. R. nav. med. Serv. 64.

\section{Discussion}

Dr. E. C. Owen (Hannah Dairy Research Institute, Kirkhill, Ayr) asked why proteins were classed as first and second class and whether plant protein could be efficiently extracted from the cell.

Dr. H. Scarborough (Royal Infirmary, Edinburgh) suggested that plant protein is more efficient than animal in increasing plasma protein. He supported Ungley's findings that gingivitis is not cured by ascorbic acid or nicotinic acid administered separately or together.

Dr. E. C. Owen wished further to know whether the protein requirement for sustained hard exercise, such as rowing or swimming, is higher than that for intermittent hard exercise such as playing football. He stressed the importance of confirmation by more than one observer of any claim that a newly discovered vitamin is essential to man, and that the symptoms described are specific.

Sir John Orr (Rowett Research Institute, Bucksburn, Aberdeen) pointed out that, so far, no standard for magnesium requirements had been set up. He asked Dr. Duckworth whether he would care to make a statement on this subject and whether he considered it possible that deficiency might occur with diets in common use.

Dr. J. Duckworth (Rowett Research Institute, Bucksburn, Aberdeen) stated that he was preparing for publication a statement on magnesium requirements. There was no time then to discuss the details but he could say that the evidence he had collected indicated that poor class diets were inadequate in magnesium.

vor. 1, 1944] 